\title{
Application of foliar spray of gibberellic acid and nitrogen on the Marigold quantitatively and qualitatively (Tagetes erecta and Tagetes patula $\mathrm{L}$.)
}

Sajjad Ali ${ }^{*}$, Sami Ullah ${ }^{2}$, Muhammad Hashim Khan ${ }^{3}$, Fazli Rahim ${ }^{1}$, Muhammad Ishaq Khan ${ }^{1}$ and Muhammad $\mathrm{Ali}^{4}$

1. Department of Botany, Bacha Khan University, Charsadda KPK-Pakistan

2. Centre of Plant Biodiversity, University of Peshawar, KP-Pakistan

3. Department of Botany, Islamia College Peshawar, KP-Pakistan

4. Department of Biotechnology, Bacha Khan University, Charsadda KPK-Pakistan

*Corresponding author's email: sajjad_ali00@yahoo.com

Citation

Sajjad Ali, Sami Ullah, Muhammad Hashim Khan, Fazli Rahim, Muhammad Ishaq Khan and Muhammad Ali. Application of foliar spray of gibberellic acid and nitrogen on the Marigold quantitatively and qualitatively (Tagetes erecta and Tagetes patula L.). Pure and Applied Biology. Vol. 5, Issue 4, pp1225-1229. http://dx.doi.org/10.19045/bspab.2016.50147

Received: $24 / 08 / 2016 \quad$ Revised: 10/10/2016

Accepted: 16/10/2016

Online First: 09/11/2016

\section{Abstract}

A critical investigation was carried out to define the optimal amount of nitrogen and gibberellic acid to produce quality of flowers in Marigold flower during 2011-2012. The research was passed carried out randomly in seven Blocks and doses comprised six degrees of nitrogen (weekly and fourteen days periodically), doses of GA3 (0,50 and $100 \mathrm{ppm}$ ) and two cultivars (Tagetes erecta and Tagetes patula). The $65.94 \mathrm{~cm}$ of plant height was noted with nitrogen 1000 ppm per week and $\mathrm{GA}_{3} 100 \mathrm{ppm}$ utilized double. $\mathrm{GA}_{3}$ at $50 \mathrm{ppm}$ form buds of $1.83 \mathrm{~cm}$ in size. $6.96 \mathrm{~cm}$ flower diameters were eminent having nitrogen dose of 500 while $\mathrm{GA}_{3}$ of $50 \mathrm{ppm}$. Nitrogen of $1000 \mathrm{ppm} /$ week determined a sum of 7.25 flowers per plant. $58.25 \mathrm{~cm}$ were the stem length noted treated by 1000 ppm/week of Nitrogen and GA 3 .

Keywords: Gibberellic acid; Nitrogen; Tagetes

\section{Introduction}

It is usually known as marigold, used as ornamental plant. It is native to Mexico known as Mexican marigold and also called Azetic marigold. Marigold is also native to Central America. In Pakistan it is used as economically purpose. Marigold is also cultivated as an edging species on many herbaceous borders. It also used in those areas where the water is less because watering of marigold field done easily. In a single field its mixed variety like red, yellow where commonly cultivated. The aims of present study are how we can improve flowering and its yield, by nitrogen and gibberellic acid.

\section{Material and methods}

The practical work was conceded out at NIFA (Nuclear Institute for Food and Agriculture) using two cultivars namely 
Tagetes erecta and Tagetes patula. Before starting the work $10 \mathrm{~kg}$ FYM (Frame Yard Manure), 20 gm Nitrogen, 25 gm of $\mathrm{P}_{2} \mathrm{O}_{5}$ and $15 \mathrm{gm} \mathrm{K}_{2} \mathrm{O} / \mathrm{m}^{2}$ combined in rows were used. The applications of Nitrogen were used in two intervals that are 7.5 gm during plantation and remaining were applied after 45 days. While spray of Nitrogen were implemented at the start of $1^{\text {st }}$ month. Mainly spray were applied during the morning time $0.05 \%$ of T-pol, were used as surface active agent. Doses of Nitrogen were 200, 500 and 1000 ppm was used at 7 days and 14 days at regular periods. Doses of $\mathrm{GA}_{3}$ were 50 and 100 ppm was used with 2 intervals. The initial spray was applied just after planting while $2^{\text {nd }}$ spray was applied when it attend a height of $15-20 \mathrm{~cm}$. For compression the control was run simultaneously. Plants were planted with 60 x $60 \mathrm{~cm}$ row to row and plant to plant. $4 \mathrm{~m}^{2}$ areas were devoted for the experiment. Spaces between the beds were $4 \mathrm{ft}$. Data was analyzed statistically by using factorial R.B.D.

\section{Result and discussion}

In over all the species of marigold i.e Tagetes patula $(59-63 \mathrm{~cm})$ was established meaningfully heighted than Tagetes erecta $(44-56 \mathrm{~cm})$ (Table 1) which is due to the variance in their genomic composition. Substantial rise in plant species over control was saw just when marigold were sprayed either with Nitrogen 500 ppm at 7 days or with $1000 \mathrm{ppm}$ of its application at 7 or 14 days. [1] The height marigold $(61,32 \mathrm{~cm})$ were noticed when the dose of Nitrogen (1000 ppm) were sprayed at 7 days intervals. Distinct species also presented alike performance to the application of Nitrogen as their combined activity. Rise in marigold height after submission to Nitrogen does may probably be endorsed to feature of Nitrogen in cell formation also in synthesis of protein which eventually improves the somatic growth [2]. These reports are in line with Arora and Saini (1975) that nitrogen spray raises the height of plant. The level of $\mathrm{GA}_{3}$ rise the height of marigold over the control. The maximum height of plant $(60.07 \mathrm{~cm})$ was noted with the application of $\mathrm{GA}_{3} 100$ ppm. Muknopaddhyay (1990), Artherton and Haris (1980) also reported increase height of marigold due to application of Nitrogen does that what the present finding show. Stem of cultivar Tagetes patula $(54.01 \mathrm{~cm})$ was extensive as compared to Tagetes erecta $(47.32 \mathrm{~cm})$. As concerns the nitrogen effect on the length of stem, it was rise by all application with supreme length of stem of $53.76 \mathrm{~cm}$ when the marigolds were sprayed with nitrogen. Sprayed with maximum height of stem $53.85 \mathrm{~cm}$ when marigolds were treated with $1000 \mathrm{ppm}$ at 7 days intervals). Rise in the length of stem were observed due to rise in the length when were more when the marigold were treated with nitrogen does. Further increase in the concentration of $\mathrm{GA}_{3}$ formed in the manufacture of height stem as associated to the low amount. The communication of $\mathrm{GA}_{3}$ and Nitrogen showed that increase length of stem $(57.24$ $\mathrm{cm})$ was documented when $\mathrm{GA}_{3} 100$ ppm was sprayed and also nitrogen (1000 ppm) at 7 days interveals. Rise in the length of stem got with $\mathrm{GA}_{3}(100 \mathrm{ppm})$ is maintained by the report of $[3,4]$. Flower bud of "Tagetes patula" $(1.78 \mathrm{~cm})$ was greater than "Tagetes erecta" $(1.65 \mathrm{~cm})$ (Table 2). The rise in size of bud $(1.78 \mathrm{~cm})$ was verified with nitrogen 200 ppm per 7 days. So certain tendencies in the size of bud were not noticed under dissimilar level of nitrogen. Other factors may be apart from nitrogen, which take part in the germination of bud. While in contrast to the entire level of $\mathrm{GA}_{3}$ increased the size of bud meaningfully. Height buds $(1.82 \mathrm{~cm})$ were reported with $\mathrm{GA}_{3} 50 \mathrm{ppm}$ and more increase in $\mathrm{GA}_{3}$ reduced the size of bud. A part of $\mathrm{GA}_{3}$ in increasing the size of bud may be recognized to translocate the 
metabolite at the area of bud growth. Tagetes patula cultivar formed many flowers at per plant than "Tagetes erecta". Huge number of flower on each plant (7.24) was noted when sprayed of nitrogen (1000 ppm) at 7 days intervals. The nitrogen absorption showed increases the flower number on each plant. Though 7 days of application of nitrogen does exposed dominant result report are same with $[5,6]$. $\mathrm{GA}_{3}$ also improved the flower number on each plant, which is in conformity the finding of $[6,7] . \mathrm{GA}_{3}$ effect were also reported by winter annuals (Singh 1996) cultivar "Tagetes patula" presented additional \% of calyx (20.80) then Tagetes erecta (17.79) (Table 3). The height number of calyx splitting (22.07) was reported in control, while the low (14.00) was reported with doses of Nitrogen 1000 ppm per 7 days. A decline in split calyx proportion at comparatively huge Nitrogen level was also reported previously by winsor et al. (1970). Arota and Saini (1975) also documented a decrease in spliting calayx with large Nitrogen does. Significantly the sizes of flower were varied. Tagetes patula created flower of high diameter than Tagetes erecta (Table 4a): high diameter of flower (6.76 $\mathrm{cm})$ was reported with Nitrogen $500 \mathrm{ppm}$ per 7 days and 50 ppm $\mathrm{GA}_{3}$. The application of area $(3 \mathrm{~g} / 1)$ was found to rise the size of flower in Chrysanthemum and 7 days, 14 days were greater to fortnightly application for size of flower (Singh 1980). The height size of flower with the application of $\mathrm{GA}_{3}$ $(50$ ppm) were also stated by Muknoyadhyay (1990).

Table 1. Effect of nitrogen and GA3 sprays on plant height $(\mathrm{cm})$

\begin{tabular}{|l|l|l|l|l|l|l|}
\hline $\begin{array}{l}\text { Nitrogen(ppm)/ } \\
\text { Intervals }\end{array}$ & Tagetes erecta & Tagetes patula & Mean & \multicolumn{3}{|c|}{ GA3 (ppm) } \\
\cline { 5 - 7 } Control & & & & $\mathbf{1 0 0}$ & $\mathbf{5 0}$ & $\mathbf{0}$ \\
\hline 200/week & 63.15 & 72.58 & 67.86 & 69.65 & 68.35 & 65.59 \\
\hline 200/fortnight & 63.57 & 72.80 & 68.19 & 69.79 & 68.26 & 66.61 \\
\hline 500/week & 62.75 & 72.55 & 67.65 & 68.86 & 67.82 & 66.28 \\
\hline 500/fortnight & 66.68 & 74.86 & 70.77 & 72.28 & 70.68 & 69.35 \\
\hline 1000/week & 63.65 & 72.68 & 68.16 & 69.72 & 67.87 & 66.88 \\
\hline $\mathbf{1 0 0 0 / f o r t n i g h t ~}$ & 67.86 & 76.80 & 72.33 & 75.94 & 71.73 & 69.33 \\
\hline Mean & 64.95 & 74.06 & 69.51 & 71.30 & 69.70 & 67.51 \\
\hline
\end{tabular}

Table 2. Effect of nitrogen and GA3 sprays on bud size (cm)

\begin{tabular}{|l|l|l|l|l|l|l|}
\hline $\begin{array}{l}\text { Nitrogen(ppm)/ } \\
\text { Intervals }\end{array}$ & Tagetes erecta & Tagetes patula & \multirow{2}{*}{ Mean } & \multicolumn{3}{|c|}{ GA3 (ppm) } \\
\cline { 5 - 7 } & & & & $\mathbf{1 0 0}$ & $\mathbf{5 0}$ & $\mathbf{0}$ \\
\hline Control & 0.05 & 0.08 & 0.06 & 0.04 & 1.83 & 0.05 \\
\hline $\mathbf{2 0 0 / w e e k}$ & 0.07 & 0.08 & 0.09 & 0.50 & 1.20 & 0.60 \\
\hline $\mathbf{2 0 0 / f o r t n i g h t ~}$ & 0.05 & 0.05 & 0.05 & 0.89 & 1.01 & 1.20 \\
\hline $\mathbf{5 0 0 / w e e k}$ & 0.08 & 0.06 & 0.07 & 0.65 & 0.13 & 1.00 \\
\hline $\mathbf{5 0 0 / f o r t n i g h t ~}$ & 0.05 & 0.08 & 0.06 & 0.78 & 0.05 & 0.59 \\
\hline $\mathbf{1 0 0 0 / w e e k}$ & 0.06 & 0.00 & 0.03 & 0.51 & 1.00 & 0.56 \\
\hline $\mathbf{1 0 0 0 / f o r t n i g h t ~}$ & 0.05 & 0.06 & 0.01 & 0.67 & 1.01 & 0.89 \\
\hline Mean & 0.66 & 0.06 & 0.053 & 0.57 & 0.89 & 0.69 \\
\hline
\end{tabular}


Table 3. Effect of nitrogen and GA3 sprays on numbers of flower

\begin{tabular}{|l|l|l|l|l|l|l|}
\hline $\begin{array}{l}\text { Nitrogen(ppm)/ } \\
\text { Intervals }\end{array}$ & Tagetes erecta & Tagetes patula & \multirow{2}{*}{ Mean } & \multicolumn{3}{|c|}{ GA3 (ppm) } \\
\cline { 5 - 7 } & & & & $\mathbf{1 0 0}$ & $\mathbf{5 0}$ & $\mathbf{0}$ \\
\hline Control & 3.40 & 6.78 & 5.09 & 2.10 & 4.50 & 3.28 \\
\hline $\mathbf{2 0 0 / w e e k}$ & 4.10 & 5.69 & 4.895 & 2.45 & 4.61 & 3.11 \\
\hline $\mathbf{2 0 0 / f o r t n i g h t ~}$ & 4.28 & 5.31 & 4.795 & 2.11 & 4.05 & 3.02 \\
\hline 500/week & 5.60 & 5.21 & 5.405 & 3.16 & 5.03 & 4.01 \\
\hline 500/fortnight & 4.90 & 5.61 & 5.255 & 3.17 & 4.51 & 4.51 \\
\hline 1000/week & 5.89 & 5.02 & 6.805 & 3.81 & 4.36 & 3.62 \\
\hline 1000/fortnight & 6.78 & 7.72 & 7.25 & 3.67 & 5.01 & 4.24 \\
\hline Mean & 4.992 & 5.905 & 5.642 & 2.924 & 4.581 & 3.684 \\
\hline
\end{tabular}

Table 4. Effect of nitrogen and GA3 sprays on diameter of flower

\begin{tabular}{|l|l|l|l|l|l|l|}
\hline $\begin{array}{l}\text { Nitrogen(ppm)/ } \\
\text { Intervals }\end{array}$ & Tagetes erecta & Tagetes patula & Mean & \multicolumn{3}{|c|}{ GA3 (ppm) } \\
\cline { 4 - 7 } & & & & $\mathbf{1 0 0}$ & $\mathbf{5 0}$ & $\mathbf{0}$ \\
\hline Control & 1.23 & 1.56 & 1.395 & 1.15 & 2.31 & 1.30 \\
\hline $\mathbf{2 0 0 / w e e k}$ & 1.21 & 2.34 & 1.775 & 1.31 & 2.00 & 1.04 \\
\hline $\mathbf{2 0 0 / f o r t n i g h t ~}$ & 1.11 & 2.12 & 1.615 & 1.23 & 2.50 & 3.13 \\
\hline $\mathbf{5 0 0 / w e e k}$ & 3.50 & 3.46 & 3.48 & 1.34 & 1.87 & 1.23 \\
\hline $\mathbf{5 0 0 / f o r t n i g h t ~}$ & 2.01 & 2.34 & 2.175 & 1.56 & 1.90 & 1.43 \\
\hline $\mathbf{1 0 0 0 / w e e k}$ & 2.02 & 2.13 & 2.075 & 2.10 & 2.10 & 1.23 \\
\hline $\mathbf{1 0 0 0 / f o r t n i g h t ~}$ & 1.89 & 2.00 & 1.945 & 2.00 & 3.12 & 1.84 \\
\hline Mean & 1.86 & 2.278 & 2.066 & 1.527 & 6.96 & 1.6 \\
\hline
\end{tabular}

\section{Authors' contributions}

Conceived and designed the experiments: $S$

Ali \& S Ullah, Performed the experiments: MH Khan \& F Rahim, Analyzed the data: MI Khan \& M Ali, Contributed reagents/ materials/ analysis tools: M Ali \& S Ullah, Wrote the paper: S Ali \& S Ullah.

\section{References}

1. Arora JS \& Saini SS (1975). Response of carnation (Dianthus caryophyllus L.) to various levels of $\mathrm{N}, \mathrm{P}$ and $\mathrm{K}$ fertilization. Journal of Research, Punjab Agricultural University, Ludhiana 13(4): 362-66.

2. Atherton JG \& Harris GP (1980). Effect of photoperiod on shoot elongation and endogenous gibberellins in the glasshouse carnation. Scientia Horticulture 12: 83-88.

3. EL-Shafie (1980). Preliminary studies on the effect of gibberellic acid on the growth and flowering of carnation plant (D. caryophyllus L.). Monufeia Journal of Agricultural Research 3: 369-385.

4. Jana BK \& Kabir J (1987). Response of growth regulators on growth and flowering of carnation cv. Improved Marguerite. Progressive Horticulture 19 (1-2): 125-127.

5. Jhon AQ \& Arora JS (1978). Differential uptake of $\mathrm{N}, \mathrm{P}$ and $\mathrm{K}$ by carnation plants, under varying levels of nitrogen, their time of application and plant density. Indian Journal of Horticulture 35 (1): 58-61.

6. Mengel K \& Kirkby EA (1987). Principles of plant nutrition, 4th ed: Panima Publishing Corporation. New Delhi pp.677.

7. Mukhopadhyay A (1990). Responses of carnation to spray application of NAA and Gibberellic acid. Haryana Journal 
of Horticultural Science 19 (3-4) : 280283.

8. Mynett K (1979a). Effect of exogenous growth regulators on flower stalk and bud development in glasshouse carnations. Prace. Instytutu Sadownictai Kwiaciarstwa Wikiernie Wicach, B 4: 70-84.

9. Patel KS \& Arora JS (1986). Effect of pincing, source and doses of $\mathrm{N}$ on the growth and flower production of carnation cv. Marguerite White. Indian Journal of Horticulture 43 (1-2): 92-97.

10. Singh B (1986). Foliar application of fertilizer mixtures for chrysanthemum.
South Indian Horticulture 34 (5): 367369.

11. Singh BP (1966). Influence of Gibberellic acid on vegetative growth and flowering of winter annuals. Science and Culture 32 (11): 551-552.

12. Winsor GW, Long MIE \& Hart BMA (1970). The nutrition of glasshouse carnation. J of Hortic Sci 45: 401-413.

13. Girisha R, Shirol AM, Kulkarni BS, Reddy BS \& Anupa T (2012). Studies on effect of different plant growth regulators on growth, flowering and quality of daisy (Aster amellus L.) cv. Dwarf Pink. Int $J$ of Agric, Envir \& Biotech 5(2). 